\title{
EPOS CIRILLO-METODIADA V PERIPETIÁCH LITERÁRNOHISTORICKEJ RECEPCIE
}

\section{The Epos Cirillo-Metodiada in Peripeteias of Literary Historical Reception}

\author{
Martina Taneski
}

DOI: 10.17846/CL.2018.11.2.143-150

\begin{abstract}
TANESKI, Martina. The Epos Cirillo-Metodiada in Peripeteias of Literary Historical Reception. The aim of this study is not a redundant accumulation of different opinions or exhausting cross-section of all present literary critical evaluations of the epos CirilloMetodiada, but, especially, reflective and problematic viewing on selected facts influencing the reception of this work in past and nowadays. Therefore, the first part of the study outlines the question of usefulness or uselessness of the interpretative returns to works of literary past. In that manner we create the platform for the second part in which we try to notice discrepancy between the author's intention of Ján Hollý and incomplete grip of this intention by readers and cultural public of the particular era. We base from the well-known terminology of Umberto Eco which represent the discrepancy between the author's and reader's intention, while independently from both of these intentions persist the intention of the literary text itself. In the third part we think about the epos Cirillo-Metodiada in context of the efforts for an intra literary translation of the work of Ján Hollý, while the motivation we see in its updating and also accessing to wider base of readers.
\end{abstract}

Keywords: Ján Hollý, Cirillo-Metodiada, literary history, author's intention, intra literary translation

\begin{abstract}
Abstrakt: TANESKI, Martina. Epos Cirillo-Metodiada v peripetiách literárnohistorickej recepcie. Ciel’om štúdie nie je redundantné hromadenie názorov či vyčerpávajúci prierez všetkých doterajších literárno-kritických hodnotení eposu Cirillo-Metodiada, ale predovšetkým reflexívne problémové nazeranie na vybrané skutočnosti, ovplyvňujúce recepciu tohto diela v minulosti a dnes. Prvá čast príspevku preto načrtáva otázku (ne)potrebnosti neustávajúcich interpretačných návratov $\mathrm{k}$ dielam literárnej minulosti, čím sa vytvára platforma pre druhú čast', v ktorej sa pokúšame zaznamenat diskrepanciu medzi autorským zámerom Jána Hollého a neúplným uchopením tohto zámeru dobovou čitatelskou a kultúrnou verejnostou. Opierame sa o známu terminológiu Umberta Eca, ktorá vystihuje nesúlad medzi zámerom autora a zámerom čitatela, pričom nezávisle od oboch týchto zámerov pretrváva zámer samotného textu diela. Tretia čast' uvažuje o Cirillo-Metodiade v kontexte snáh o vnútroliterárny preklad tvorby Jána Hollého, čoho motiváciou bolo jej aktualizovanie a širšie čitatelské sprístupnenie.
\end{abstract}

Klúčové slová: Ján Hollý, Cirillo-Metodiada, literárna história, recepcia, autorskýzámer, vnútroliterárny preklad 


\section{Návraty k dielam starších literárnych období}

Neustále prehodnocovanie je priam signifikantnou črtou súčasných literárnohistorických výskumov, ktoré okrem bádania a skúmania literárnej minulosti s cielom objavovat nepoznané čoraz častejšie znovuobjavujú a reinterpretujú.

Valér Mikula $(2013,5)$ sa k takýmto postupom vyjadruje už aj v súvislosti s charakterom našej spoločnosti kritickejšie: „Toto paradoxné rozpoloženie - čakanie na niečo, čo bolo - spôsobuje, že u nás dochádza, tiež paradoxne, $\mathrm{k}$ faktickému nedoceňovaniu minulosti a zároveň $\mathrm{k}$ preceňovaniu toho, čo sa o nej povie, napíše. Akoby samotný fakt kritického podania mohol tú minulost' zmazat', kým nadšený prístup akoby ju budoval! Skrátka, u nás sa skôr čaká na Dejiny a menej sa vraciame k tomu, čo sa skutočne udialo.“ Nemožno nesúhlasit’ s tým, že takmer symptomatické sú v tomto zmysle viaceré súčasné i nedávno minulé literárnohistorické práce a štúdie, na ktoré, domnievam sa, Valér Mikula v úvode svojej monografie s príznačným titulom Čakanie na dejiny (2013) taktne narážal, avšak za obzvlášt pozitívny „vedlajší produkt“ viacerých monografí, štúdií, interpretácií a z nich vyplývajúcich diskusií treba považovat aktualizáciu literárnohistorických tém, ak aj nie pre širšie spoločenské dianie, iste aspoň pre tých niekolkých jednotlivcov mladších generácií so záujmom o dejiny literatúry a zložitý proces ich formovania v kontakte s historicko-spoločenským vývinom, alebo ešte väčšmi pre tých, ktorí podlahli vlne súčasných konšpiračných teórií a neschopnosti ocenit’ historický fakt či umelecké dielo. Z tohto uhla pohladu sa ako nadčasovo platná javí taktiež myšlienka Jána Bakoša $(2000,21)$ : „Umelecké dielo treba interpretovat’ jednoducho preto, že sa mení historická povaha umenia, a bez historickej rekonštrukcie vývinovej súvislosti nie sme schopní adekvátne ani vnímat', ani ocenit vlastný obsah diela, t. j. jeho vývinové miesto, preto vývinová rekonštrukcia je vlastne aktualizáciou diela.“

Obhájenie načrtnutých prístupov ku skúmaniu starších literárnych období slovenskej literatúry nateraz však nemusí byt' procesom zdlihavým, najmä ak zohladníme objektívnu skutočnost', že dejiny každej národnej literatúry majú svojich tvorcov, ktorí na diela, udalosti a okolnosti ich vzniku nazerajú spravidla cez paradigmu úrovne dobového vedeckého poznania, filozofického smerovania, neopomínajúc väčšiu či menšiu mieru subjektívneho vkladu, obzvlášt pri hodnotení umelecko-estetických kvalít textov, pričom nezriedka v týchto hodnotiacich procesoch dochádza aj k uplatňovaniu axióm a teorém dobovo aktuálneho politického režimu. V prípade takzvaných malých literatúr je mnohovrstevný, a zároveň abruptný proces formovania dejín národnej literatúry navyše poznačený neustálym vymedzovaním vlastnej identity, čo je proces neraz natolko komplikovaný, že v niektorých obdobiach absentuje akékolvek exaktné poznanie o genéze literárneho vývinu, nehovoriac o vývine jazyka, či plynulom rozvíjaní medziliterárnych kontaktov. Nezriedkavý je v tejto súvislosti jav, ked’ sa o dvojdomých a viacdomých autorov delia dve alebo viaceré národné literatúry, a teda na tej istej konferencii môže prednášat slovenský literárny vedec o Pavlovi Jozefovi Šafárikovi a český historik o Pavlovi Josefovi Šafař́íkovi. ${ }^{1}$

Doposial' uvedené fakty predstavujú oporu nami zaujímaného stanoviska o nevyhnutnosti nepretržitého vyhodnocovania širokého diapazónu kritických pohladov na konkrétne literárne dielo zo synchrónneho aj diachrónneho hladiska, a to s prihliadnutím na skutočnost', že dielo vzniklo a pôsobilo nielen v krátkom intervale literárnohistorického vývinu, a teda nemožno ho vnímat iba ako akýsi literárnohistorický artefakt, ale zostáva predovšetkým nositelom obsahu a formy, a ako také disponuje menším či významnejším recepčným dobovým presahom, a preto môže byt v novších interpretáciách aktualizované, pričom takýto proces generovania hodnotení systematicky zobjemňuje množinu pulzujúcich úvah o (ne)konštantnosti potenciálu konkrétneho

Podrobne sa viacdomostou autorov, ako aj dalšími otázkami z oblasti problematiky medziliterárnych spoločenstiev vo svojej práci Teória medziliterárneho procesu I. (1995) zaoberal Dionýz Ďurišin. 
literárneho diela. Otázka, ktorú si v súvislosti s eposom Cirillo-Metodiada (1835) v úvode kladieme, teda spočíva $\mathrm{v}$ možnostiach prehodnotenia jeho významu a miesta v dejinách slovenskej literatúry.

\section{Cirillo-Metodiada vo vývinovo-rekonštrukčnom nazeraní}

Opätovné skúmanie postavenia duchovného eposu Cirillo-Metodiada ${ }^{2}$ v dejinách slovenskej literatúry je opodstatnené aj skutočnostou, že v diachrónne meniacom sa pohlade na význam tvorby Jána Hollého zaznamenávame diametrálne odlišné hodnotenia, neraz až nedocenenie a v nedávnej minulosti i hroziace dejinné „opomenutie“ pre jeho nevyhovujúci kádrový posudok. Tým druhým opodstatnením je nemenej pozoruhodná okolnost', že Cirillo-Metodiada v ohlasoch z obdobia bezprostredne po jej vydaní v porovnaní so Svatoplukom (1833) výrazne zaostáva. Ide o fakt, ktorý neprekryje (Mikulom titulovaný) „nadšený prístup“ žiadnych neskorších ani súčasných snáh o docenenie eposu, čím ale, pochopitel’ne, nespochybňujeme potrebu interpretácie tohto diela $\mathrm{z}$ dôvodu jeho aktualizácie ${ }^{3}$.

S poznaním, že za najobjektívnejší atribút literárneho diela samého osebe možno považovat’ jedine zámer textu, ktorý ale nemusí (a s najväčšou pravdepodobnostou ani nemôže) byt' totožný so subjektivizujúcimi zámermi čitatelov - literárnych kritikov a historikov každej literárnohistorickej epochy nevynímajúc - javí sa z perspektívy súčasného skúmania vhodné zamerat sa najprv na faktami postihnutel'nejší zámer autora ${ }^{4}$, a to najmä preto, že vd’aka Jozefovi Ambrušovi máme k dispozícii editorsky zostavenú a poznámkovo prepracovanú Korešpondenciu Jána Hollého (1967). V tejto precíznej editorskej práci nachádzame spolahlivý a doteraz nevyčerpaný prameň, prostredníctvom ktorého môžeme aspoň do určitej miery konfrontovat pôvodný zámer autora s následnou bezprostrednou i neskoršou dobovou recepciou duchovného eposu Cirillo-Metodiada.

Reflektujúc vysokú umelecko-estetickú hodnotu Hollého časomerných eposov, ktoré v duchu klasicistických tvorivých postupov mali ambíciu prekonávat svoje antické predlohy ${ }^{5}$, mienime sa zamerat predovšetkým na ideologické pozadie a motivácie ich vzniku. Ján Hollý v intenciách aktuálnych spoločenských udalostí obrodzovacieho procesu s vypätím realizoval svoj ideologický autorský zámer, ktorý charakterizuje historicko-spoločenská uvedomelost', konceptuálnost’ a ideologické zacielenie v prospech myšlienky svojbytného národa s vlastným jazykom, literatúrou, dejinami a kultúrou. Preto, ak uvažujeme o Cirillo-Metodiade, nemôžeme nevnímat’ ju v širšom kontexte a v úzkom prepojení s eposmi Svatopluk a Sláv (1839), čo vo svojich autorských dejinách literatúry dôvodne formuloval Stanislav Šmatlák (2001, 33): „Trojica týchto eposov, spracúvajúca látku národnej proveniencie, je výsledkom premyslenej umeleckej, ale aj kultúrnohistorickej koncepcie Hollého hrdinskej epiky: Svatopluk mal ukázat štátnomocenskú slávu našich slovanských predkov, Cirillo-Metodiada mala poukázat’ na ich silu duchovnú a napokon Sláv mal oživit ich starobylost̉ mytologickú.“

2 Zaradenie eposu Cirillo-Metodiada k eposom duchovným je nielen náležité, ale v súčasnosti už aj učebnicovo zaužívané, čím ale nechce a nemôže byt’ opomenutý zrejmý historizujúci charakter diela. Tento fakt je o to dôležitejší, že u Jána Hollého história (dejiny národa) vždy napreduje po boku s duchovnom (s upevňovaním viery).

3 Viaceré zaujímavé štúdie nachádzame napríklad v súčasných zborníkoch vedeckých prác: Literárnohistorické kolokvium IV. Klasicizmus (2017) či Slová Slovanov (2013), ale aj v časopise Konštantínove listy (Mihalková 2017, 165-177).

4 Podrobnejšie k teórii interpretácie literárneho diela a použitej terminológii: Eco 1995, Eco 2009.

5 Bližšie o Hollého cielenom prekonávaní antických literárnych predlôh napríklad v príspevku M. Taneski (2017, 78-88). 
Oporu Hollého kultúrnohistorickej koncepcii s dôrazom na duchovný prerod Slovákov poskytovalo predovšetkým precízne štúdium publikovaných vedeckých a odborných prác, ktoré zaznamenávali dejiny vel'komoravského obdobia na úrovni dobovo aktuálnych poznatkov. ${ }^{6} \mathrm{~V}$ liste pre Juraja Palkoviča z júla 1829 píše: „Ďekujem téš za pozbirané správi o Svatoplukovi, že tolkú prácu a unováňi pre mňa podstúpit ráčili. Já sem si podobné vedomosti ze Života ss. Cirilla a Metóda od nebohého p. Dobrovského vidaného a s priloženéj na konci chronologie spísal." (Hollý 1967). Z citovaného vyplýva, že už počas písania Svatopluka nadobúdal materiály potrebné pre CirilloMetodiadu, čo možno považovat' za jeden z prejavov systematického prístupu smerujúceho k naplneniu pre neho bytostne dôležitej autorskej stratégie.

V neskoršom liste adresovanom Martinovi Hamuljakovi nachádzame taktiež Hollého reflexiu uhorských eposov, ktoré - ak by splňali náročné žánrové a vysoké slohové kritériá - ohrozovali by jeho autorský zámer, spočívajúci vo vytvorení jedinečných diel, akými nedisponujú iné, menšie, ale ani väčšie slovanské národy. Že sa o uhorskú literatúru vysokého slohu s istými obavami aktívne zaujímal, dosvedčuje jeho prosba o zaslanie Horvátovho eposu Árpád (1831): „Počul sem, že jakási uherská Arpadiaš či Arpadiaša aneb Arpadiada višla. Rád bich ju čítal. Že je pinguis Minerva, povedal jeden Polouher, čo ju čítal.“ (Hollý 1967). Tento epos zachytáva dejiny Madarov a je koncipovaný podobne ako Vergíliova Eneida. Z hladiska umelecko-estetického tento pokus do značnej miery - iste aj k spokojnosti Jána Hollého - skutočne vystihuje označenie „pinguis Minerva“, preto ho neocenila ani vyššia uhorská spoločnosț. Trojicou bernolákovských eposov (historickým, duchovným a mytologickým) napokon Hollý s jednoznačným odporom zareagoval na takzvanú podmanitel'skú teóriu, ktorú pertraktovali aj d’alšie uhorské eposy.

Súčastou Hollého ideológie bolo aj rozvinutie rodiaceho sa kultu Tatier, čím sa priblížil nastupujúcej štúrovskej generácii. Nestalo sa tak ale prostredníctvom veršov uznávaného Svatopluka, ale je to práve Cirillo-Metodiada, ktorá začína dvojverším: „Prospevujem, jak viprosení s Cárihradu bratri, Konštantín a Metód, ku tatranskím došli Slovákom“ (Hollý 1950, 11). Eva Fordinálová $(2003,198)$ v tejto súvislosti uvádza, že „medzi eposmi Cirillo-Metodiada a Sláv nemožno si nepovšimnút ešte dalšiu analógiu - teraz bez potreby prehodnocovania: ide o kult Tatier. Isteže, jeho vznik nemožno pripísat' Hollému (počas svojho života ich nikdy nevidel). Tatry ako synonymum slovenskosti povýšila na symbol mladá nastupujúca romantická generácia. Ale práve čas „rodenia sa" tohto symbolu možno v Hollého tvorbe pozorovat." Na základe početných zmienok o Tatrách a „tatranských“ Slovákoch v epose Cirillo-Metodiada d’alej usudzuje, že Hollý národnú symboliku Tatier bez výhrad prijíma, a to aj napriek zmienkam o „nitrianskych“ a „panónskych“ Slovákoch, ktorých využitie bolo ideovo motivované vzhladom na jeho rozvíjajúci sa autorský zámer v epose Sláv.

V dejinách slovenskej literatúry nachádzame obdobia, ked’ dielo Jána Hollého muselo odolávat viac či menej negatívnej kritike, no čo je horšie než kritika samotná, je zámerné nereflektovanie (napríklad režimovo) nežiaduceho diela. V súčasnosti môžeme zhodnotit, že v druhej polovici 20. storočia tragickému scenáru zámerného „opomenutia“ Hollého eposu Cirillo-Metodiada, ako aj d’alšej jeho tvorbe, zabránili predovšetkým práce spomínaného Jozefa Ambruša, ktorý okrem zostavenia Diela Jána Hollého I. - X (1950) pracoval aj na vydaní neskoršieho výberu a je tiež autorom mnohých literárnovedných štúdií a článkov. Najvýznamnejšími sa v tomto kontexte stali jeho objavné práce Ján Hollý očami svojich súčasníkov (1964) a Korešpondencia Jána Hollého, vd’aka ktorým sa mnohé o diele a živote autora objasnilo.

6 Iste, je nutné pripomenút, že Ján Hollý autorsky tvorivo prepojil historické fakty s epickou fikciou, a tiež pripomenút, že nepoznal Moravsko-pannónske legendy publikované až v roku 1851 Pavlom Jozefom Šafárikom. 
V nazeraní na literárnohistorickú recepciu diela Jána Hollého musíme opät aspoň krátko pripomenút závažnú polemiku Polakoviča a Rapanta z roku 1945, ked’ bola známa iba čast' Hollého korešpondencie. Jedným z bodov tejto polemiky bolo rozvinutie problému „Hollý verzus Kollár“. Je pravdepodobné, že by spor trval dodnes, ak by Jozef Ambruš v roku 1967 nevydal Korešpondenciu Jána Hollého, ktorá je dôkazom prinajmenšom vzájomného rešpektu medzi Jánom Hollým a Jánom Kollárom. Práve vdaka tejto editorskej práci mohol v roku 1985 Karol Rosenbaum spolahlivo formulovat svoj názor o nevyhrotenosti vztahu medzi dvoma velikánmi slovenského literárneho klasicizmu? ${ }^{7}$ Jozef Ambruš nielenže sprístupnil život a dielo popredného predstavitela slovenského literárneho klasicizmu, ale aj opravil viaceré chybné informácie dovtedajšieho literárnovedného výskumu. Koncom 20. storočia už akýkolvek systematický prístup k tvorbe Jána Hollého (Viktor Kochol, Karol Rosenbaum, Stanislav Šmatlák, Viliam Turčány, Eva Fordinálová a i.) vychádza z minuciózneho literárnovedného snaženia a jeho editorských prác.

V súvislosti s eposom Cirillo-Metodiada musíme opät konštatovat, že popri najvydávanejších Selankách a literárnovedne i čitatel'sky najreflektovanejšom epose Svatopluk až dodnes zastáva miesto v úzadí. Príčiny, pre ktoré čitatel’ská a kultúrna spoločnost’ v období jeho vzniku, ako aj neskôr, nedokázala, či skôr nemohla vyššie ohodnotit prepracovaný autorský zámer, v súčasnosti analyzuje (o. i.) Miloslav Vojtech. Svoje hodnotenia zhrnul aj v jeho najnovšej publikácii Slovenská klasicistická a preromantická literatúra (2017) a vyplýva z nich, že oproti kompozične vyváženému a dômyselne štruktúrovanému Svatoplukovi, ktorý bol koncipovaný podla vzoru Homérovej Iliady a Vergíliovej Eneidy, Cirillo-Metodiada ustrnula v stereotypnej rétorickosti bez využitia dynamického rozprávania a epickej šírky, pričom ide podla jeho názoru o nezvládnutú kompozíciu s d’alšími žánrovými nedostatkami. Vojtech $(2017,108)$ svoju syntézu uzatvára tvrdením, že „aj neskorší vývin slovenskej epickej poézie (ale aj prózy) v obrodeneckom období (zrejme aj po skúsenostiach Jána Hollého) potvrdil, že táto tematika stála mimo dobového autorského záujmu. "Napriek tomu, že sa hodnotenie Miloslava Vojtecha $(2017,104-108)$ javí ako prísne, stotožňujeme sa s jeho názorom, že Hollého cielené nadväzovanie na pomerne bohatú cyrilo-metodskú tradíciu v slovenskom i slovanskom kultúrnom povedomí ${ }^{8}$ okrem básnických alúzií v príležitostnej poézii začínajúcich romantických básnikov už nenašlo dalších výraznejších pokračovatelov.

Na základe Korešpondencie Jána Hollého zastávame názor, že práve do historicko-duchovnej Cirillo-Metodiady vkladal Hollý pre neho najvýznamnejšie tvorivé úsilie a snahu zapôsobit na spoločenské pomery, avšak ideológii nasledujúcej generácie akoby postačoval ohromujúci epos Svatopluk, ktorý predstavoval výbojnost’ potrebnú pre nadchádzajúce národnouvedomovacie snaženia. Autorsky zamýšllanú pôsobnost' Cirillo-Metodiady napokon čiastočne docielil až komplexnostou svojho diela, ktoré ako celok premyslene pertraktovalo Herderovu filozofiu

Uvádza, že Hollý sledoval tvorbu Jána Kollára a Pavla Jozefa Šafárika (píšucich v tzv. bibličtine), no - ako vyplýva z jeho listov určených Jurajovi Palkovičovi - nešlo o žiaden neprekonatel’ný spor. „Sú dôkazy o tom, že Ján Hollý a Ján Kollár, t. j. tábor biblickej češtiny, nestáli proti sebe, že ich stroho neoddelovali rozličné formy spisovného jazyka a ani odlišná konfesionálna príslušnoste ich neviedla k nepriatel’stvu. Ján Kollár nikdy a nikde neprotestoval proti bernolákovskej slovenčine takým spôsobom ako proti kodifikácii strednej slovenčiny za spisovný jazyk. (...) Ako vidno, tlmočnica Kollárových názorov Slávy dcera velmi mierne posudzuje Bernolákovu cestu, ba odvoláva sa na znášanlivost̉ a budúcnoste. (...) Obidvaja básnici majú črty spoločné i črty, ktoré ich odlišujú. Prestali však časy oddelovat ich na základe týchto čŕt a nebrat’ do úvahy to, čo ich spája." (Rosenbaum 1995, 146-147).

8 Túto tému vo svojich dielach a prácach dovtedy rozvíjali Benedikt Szöllösi, Daniel Sinapius Horčička, Matej Bel, Ján Baltazár Magin, Pavel Doležal, Samuel Timon, Juraj Papánek, Juraj Fándly, Josef Dobrovský a i. 
a kollárovsko-šafárikovské humanizačné idey.9 Avšak autorský zámer tohto eposu, spočívajúci v kontinuite prepojenia dovtedy intenzívne proklamovanej cyrilo-metodskej tradície s novou rozvíjajúcou sa symbolikou Tatier, zostal čitatelmi nepovšimnutý, a teda z pohladu samotného autora iste aj nedocenený.

\section{Vplyv vnútroliterárneho prekladu tvorby Jána Hollého na súčasnú re- cepciu}

Karol Rosenbaum, autor úvodných textov v Ambrušových edičných počinoch, vyslovil pre mnohých rozporuplnú ideu o potrebe transponovat Hollého dielo z bernolákovčiny do súčasnej slovenčiny, čo napokon čiastočne uskutočnil Ján Kostra v najvydávanejších Selankách. Vydanie z roku 1965, ktoré obsahuje aj často citovaný doslov Jozefa Felixa, znamenalo pokus o sprístupnenie a zjednodušenie recepcie diela Jána Hollého, hoci v tomto prípade chceme vyjadrit súhlas s názorom, že aj ked” „Kostrov preklad Selaniek (kompletných - i s troma záverečnými „náboženskými“ - tematika narodenia Krista) a Felixov doslov sa stretli s priaznivým ohlasom slovenskej kultúrnej verejnosti, ale bernolákovčina predsa len zostáva jedinečným pelom na motýlích krídlach Hollého poézie..." (Fordinálová 2007, 205).

Čo je najdôležitejšie, pridružila sa v druhej polovici 20. storočia otázka vnútroliterárneho prekladu, pri zodpovedaní ktorej vychádzame z tézy Viktora Kochola (1979, 121-126), ktorý uvádza, že preklad umeleckého diela nie je výlučne procesom jazykovým, ale aj tvárnym a umeleckým. Nemení sa iba jazyk, ale aj forma a tvar umeleckého textu. Tieto súvisia s ideovým obsahom diela, preto je dôležité vyhnút sa transformácii originálu na parafrázu. I ked' naším cielom nie je snaha kriticky hodnotit všetky doterajšie vydania diela Jána Hollého, no predsa len, musíme vyzdvihnút význam Ambrušovho bibliofilského spracovania Diela Jána Hollého I. - X., pri zostavovaní ktorého siahol po pôvodnom súbornom vydaní z rokov 1841 - 1842. Takéto spracovanie (iba s nevyhnutnými pravopisnými zmenami) z nášho pohladu ako jediné eliminuje akúkolvek potenciálnu hrozbu transformácie originálu na parafrázu, o ktorej sa Kochol zmieňuje. Týmto názorom však nespochybňujeme prínos vnútroliterárneho prekladu, ktorý - ako Jozef Felix tvrdil už koncom pätdesiatych rokov minulého storočia, a svedčí o tom aj Kostrov preklad Selaniek, má v literatúre svoje opodstatnenie. ${ }^{10}$

Z uvedeného vyplýva, že transponovanie Hollého tvorby z bernolákovčiny do súčasnej slovenčiny nadobúda význam predovšetkým vzhladom na potrebu sprístupnit text súčasnému čitatelovi, no domnievame sa, že ani Buzássyho preklad Cirillo-Metodiady prostredníctvom široko dostupnej edície Zlatého Fondu slovenskej literatúry z roku 1985 väčšmi nezviditel'nil pôvodný autorský zámer, ktorý v súvislosti s Hollého vtedajšími národno-obroditel’skými snaženiami už takmer ani nedokážeme komplexne postihnút. Opät’ sa presviedčame o tom, že vlažnú bezprostrednú odozvu na Hollého druhý epos nemôže nahradit dodatočná literárna kritika či reflexia, čo je pravdepodobne aj jednou z hlavných príčin sínusoidného záujmu o viaceré diela našej literárnej histórie. Bez ohladu na významné miesto Cirillo-Metodiady v Hollého premyslenej triadickej koncepcii, žil tento epos, či skôr prežíval, a tak aj dodnes prežíva - v interpretáciách s neistým potenciálom plnohodnotne uchopit velkolepo mienený autorský zámer, ktorý do neho Ján Hollý s určitostou vkladal.

\footnotetext{
9 Podrobne o vzt’ahu Jána Hollého a Ludovíta Štúra v kontexte historicko-spoločenského diania píše Eva Fordinálová v publikácii Otec a syn národa. Vztah Jána Hollého a Ludovíta Štúra (2015).

10 Podrobnejšie k tejto problematike: Tomčík 1985, 309-315.
} 
Ak sa ohliadneme za úvodnou častou tejto štúdie, musíme znova vyjadrit’ súhlas s kritickou tézou Valéra Mikulu a konštatovat, že absentujúci ohlas na epos Cirillo-Metodiada bezprostredne po jeho vydaní doposial nevykompenzovali žiadne neskoršie práce, interpretácie ani kritiky, preto $\mathrm{v}$ prípade tohto konkrétneho diela nie je $\mathrm{s}$ dlhším časovým odstupom možné ani zásadné prehodnotenie jeho miesta $\mathrm{v}$ dejinách slovenskej literatúry. $\mathrm{V}$ tomto kontexte usudzujeme, že najvýznamnejšie pôsobí druhý Hollého epos ako súčast ideologicky ucelenej koncepcie autora, no Cirillo-Metodiade samotnej tažko pripísat väčší význam než len taký, aký zohrala v období bezprostredne po svojom prvom vydaní. Napriek tomu - mikulovsky povedané - majú „dalšie state" a interpretácie tohto eposu zmysel predovšetkým v kontexte jeho aktualizácie.

\section{REFERENCES}

\section{Primary sources}

Hollý, Ján. 1950. Dielo Jána Hollého. Sväzok IV. Cirillo-Metodiada. Trnava.

Hollý, Ján. 1985. Cyrilometodiáda. In Dielo II. Bratislava, 9-175.

Korešpondencia Jána Hollého. 1967. Martin. https://zlatyfond.sme.sk/dielo/1820/Holly_ Korespondencia-Jana-Holleho/1.

\section{Secondary sources}

Bakoš, Ján. 2000. Periféria a symbolický skok. Bratislava.

Bednárová, Katarína. 2016. K niektorým otázkam vývinových trajektórií umeleckého prekladu na Slovensku (1945 - 1989) [On some aspects of developmental trajectories of literary translation in Slovakia (1945-1989)]. In World Literature Studies 8/1, 3-23.

Ďurišin, Dionýz. 1995. Teória medziliterárneho procesu I. Bratislava.

Eco, Umberto. 1995. Interpretácia a nadinterpretácia. Bratislava.

Eco, Umberto. 2009. Meze interpretace. Praha.

Fordinálová, Eva. 2015. Otec a syn národa. Vztah Jána Hollého a Ludovíta Štúra. Skalica.

Fordinálová, Eva. 2007. Ján Hollý v slovenskom národno-kultúrnom vedomí. Bratislava.

Fordinálová, Eva. 2003. Ján Hollý (1785 - 1849). Bratislava.

Fordinálová, Eva. 2013. Pretrvávajúce posolstvo Byzantskej misie v slovenskej duchovnej kultúre posolstvo pre súčasnú európsku kultúru. In Bíziková, Margita (ed.). Slová Slovanov. Bratislava, 40-48.

Kochol, Viktor. 1979. Literárne reflexie. Bratislava.

Mihalková, Gabriela. 2017. Etický rozmer reflexie vel'komoravského obdobia v slovenskej literatúre na konci 18. storočia [The Ethical Dimension of the Reflection of the Great Moravian Period in the Slovak Literature at the End of the 18th Century]. In Konštantínove listy [Constantine's Letters] 10/2, 165-177.

Mikula, Valér. 2013. Čakanie na dejiny. State k slovenskej literárnej histórii. Bratislava.

Rosenbaum, Karol. 1985. Miesto Jána Hollého v literatúre národného obrodenia. In Chovan, Juraj (ed.). Pamätnica z osláv dvojstého výročia narodenia Jána Hollého. Martin, 146-147.

Šmatlák, Stanislav. 2001. Dejiny slovenskej literatúry II. Bratislava.

Taneski, Martina. 2017. Prekonávanie vzorov ako klasicistický atribút poetiky Jána Hollého. In Brtáňová, Erika (ed.). Literánohistorické kolkvium. IV. Klasicizmus. Bratislava, 78-88. 
Tomčík, Miloš. 1985. Klasický odkaz Jána Hollého a vnútroliterárny preklad. In Chovan, Juraj (ed.). Pamätnica z osláv dvojstého výročia narodenia Jána Hollého. Martin, 309-315.

Valcerová, Anna. 2016. Tradičné a moderné, naše a cudzie ako hybné sily vývinu básnického prekladu (s dôrazom na situáciu po roku 1945) [Translation of a poetic text as an expression of national culture]. In World Literature Studies 8/1, 35-48.

Vojtech, Miloslav. 2017. Slovenská klasicistická a preromantická literatúra. Bratislava.

Vojtech, Miloslav.2013. Cyrilo-metodská tradícia v básnickom stvárnení Jána Hollého. In Bíziková, Margita (ed.). Slová Slovanov. Bratislava, 161-174.

Zajičková, Martina. 2013. Cirillo-Metodiada v národnom kontexte. In Bíziková, Margita (ed.). Slová Slovanov. Bratislava, 175-185.

\begin{abstract}
SUMMARY: THE EPOS CIRILLO-METODIADA IN PERIPETEIAS OF LITERARY HISTORICAL RECEPTION. The study deals with the question of possible reassessment of the meaning and place of Ján Hollýs epos Cirillo-Metodiada in history of Slovak literature. Ján Hollý, in the intentions of - at that time - actual social events of the revival process, hardly realized his ideological author's intention which characterize the historical and social consciousness, conceptuality and ideological aims - all in favor of the idea of independent nation with own language, literature, history and culture. In the study we prove that Ján Hollý put the most significant creative effort and also the effort to impress on social conditions pricesly into his historical and spiritual epos Cirillo-Metodiada. However, it seems that to next generation and its ideology sufficed the magnificent epos Svatopluk which presented the fight needed for another national awareness efforts. We also state that past the popular work Selanky and the most reflected epos Svatopluk the epos Cirillo-Metodiada stood at the edge of attention, because in times of publishing of this work the readers, together with cultural society, were not able to value the refined atuhor's intention. Ultimately, the meaning of the epos Cirillo-Metodiada was reached by the complexity of the author's work which as a whole thoughtfully discussed the Herder's philosophy and Kollár's and Šafárik's humanistic ideas. In this period, the author's intention of the epos, consisting in continuity of interconnection intensely proclaimed tradition of Cyril and Method, remained unnoticed from reader's view and from the view of the author, certainly, not so well appreciated. Transpose of Holly's work from Bernolak's language to contemporary Slovak takes on significance, especially, considering the need to make the text more readable to current reader, though, in the study we say that the original author's intention is not good to see not even in the translation of Ján Buzássy. Absent reaction on the epos CirilloMetodiada immediately after its first publishing is still not enough compensated - by any later work, interpretation and criticism. It means that after a long time it is not possible to reassess the place of this work in history of Slovak literature more consistently. Nevertheless, another texts and interpretations of Hollýs epos have sense, especially, in context of its updating.
\end{abstract}

PhDr. Martina Taneski, PhD.

Constantine the Philosopher University in Nitra

Faculty of Arts

Department of Slovak Language and Literature

Štefánikova 67, 94974 Nitra

Slovakia

mtaneski@ukf.sk 